\title{
Energy Costs Division and Plant Modification in a Large Research Complex: the Experience of Padova National Research Council (CNR) Area
}

\author{
Francesco Fellin ${ }^{1}$, Vanni Antoni ${ }^{2}$, Sergio Bobbo ${ }^{3}$, Lorenzo Fellin ${ }^{4}$ \\ Cesare Pagura ${ }^{5}$, Martina Spolaore ${ }^{6}$, Abramo Pellizzon ${ }^{7}$, \\ ${ }^{1,2}$ Consorzio RFX (CNR, ENEA, INFN, Università di Padova, Acciaierie Venete SpA), ${ }^{3}$ Istituto per le Tecnologie della Costruzione \\ del CNR, ${ }^{4}$ Libero professionista, ${ }^{5,6,7}$ Istituto per l'Energetica e le Interfasi del CNR
}

\begin{abstract}
The CNR area was built in the 1970s in Padova (Italy): many buildings hosting different Institutes are served by the central heating and cooling system and a common Medium and Low voltage supply. Costs division criteria, mainly based on the number of personnel units and the size of buildings of each Institute, were used in the past; due to current high costs of energy, these criteria have been revised and based on more objective parameters. This paper deals with the methods that have been studied to reduce thermal and cooling energy consumption, based on the operative conditions of buildings and specific characteristics of area HVAC (Heating Ventilation and Air Conditioning) plants. As a result of this optimization, some plant modifications have been evaluated and implemented. The results of new plant configuration and energy consumption are presented and discussed.
\end{abstract}

Keywords - district heating and cooling, energy costs division.

\section{INTRODUCTION}

The CNR area [1] was realized in the 1970s; most of the buildings are prefabricated-ground floor offices and laboratories. In the center of this Area (see Fig. 2) a multifloor building for general services hosts common areas like canteen, cafeteria, meeting rooms and the library. In the center of the area the central stations for heating/cooling and power station are also located; distribution to all the Institutes is based on underground tunnels hosting pipes and MV/LV cables trays (Fig. 4).

In the 1980s a new complex of buildings was realized to host the Institute IGI-RFX; the typology of construction is different from the other Institutes due to the scope of IGI-RFX (experiment on nuclear fusion, magnetically confined [2]). This has required a new HV substation (400 kV, 2 x 50 MVA) dedicated to RFX experiment and different HVAC systems. After IGI-RFX realization, the overall fabricated area is around 20,000 $\mathrm{m}^{2}$ (Fig. 8).

The research Area $\left(170,000 \mathrm{~m}^{2}\right)$, even if realized more than forty years ago, presents some innovative aspects like wide green areas with a large variety of trees (see Fig. 1), centralized production of cooling and heating to promote efficiency.

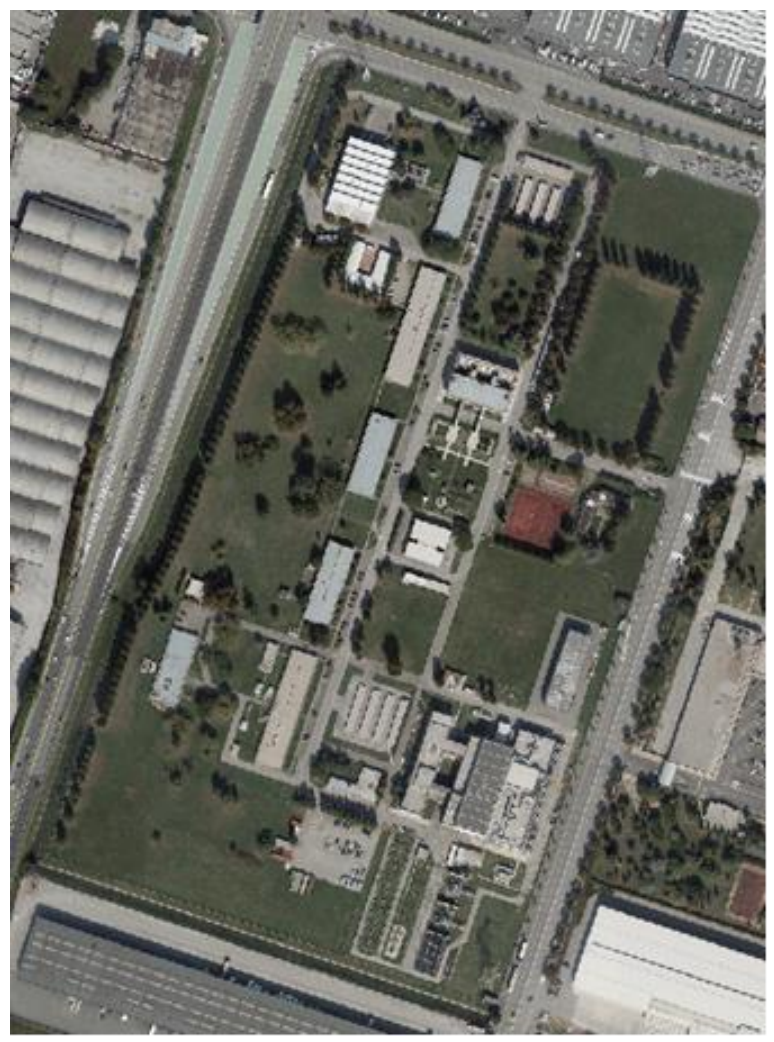

Fig. 1. Padova CNR research Area in 2007 [3].

\section{DESCRIPTION OF ELECTRICAL PLANTS}

The Area is supplied by the $20 \mathrm{kV}$ grid of "Enel distribuzione"; in the MV switchgear room fiscal energy meters are installed $(\mathrm{kW}$ peak, $\mathrm{kWh}$, kvarh, monthly average of power factor) and these values are also available for internal cost distribution, even if is a total amount only.

From this MV room, two MV lines supply the central Area power station and IGI-RFX (see Fig. 3 - at the supply point of IGI-RFX energy meters are also installed: this allows knowing exactly the electrical energy used by IGI-RFX).

The area MV power station has three MV/LV transformers: 


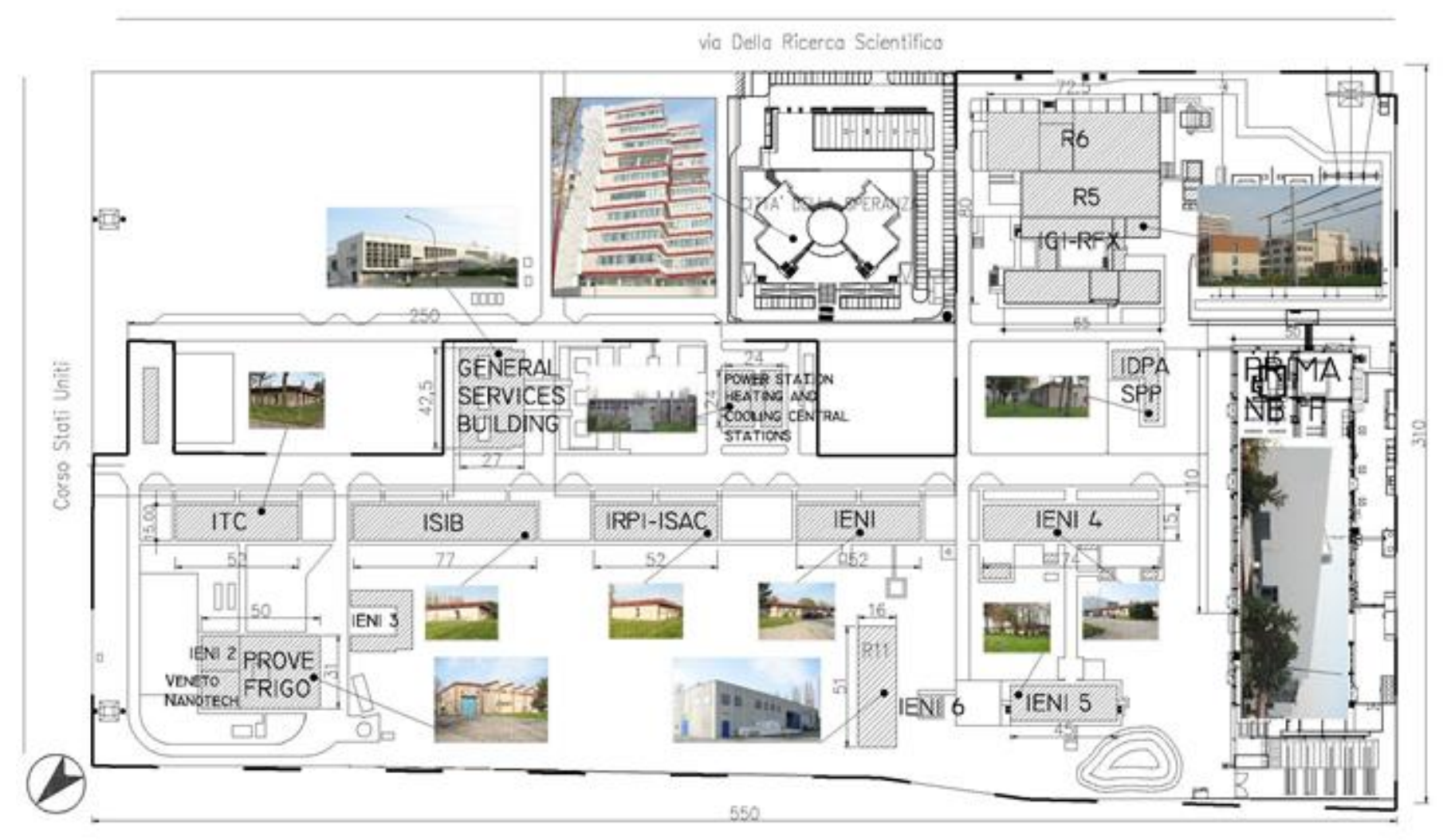

Fig. 2. Current layout of research area (included into the broken line) supplied by district cooling and heating plants (except PRIMA-NBTF). Dimensions are given in meters.

- one is dedicated to centralized cooling plants (also including pumps and evaporative towers);

- one is dedicated to illumination (L);

- one is dedicated to power distribution (F).

Finally, a MV line supplies a transformer located in the ITC Institute, where a climatic room is installed. Close to the MV cabin, the LV room hosts five LV boards, partly dedicated to general service building, other Institutes and central heating station. Energy meters are installed on the LV lines supplying the Institutes, so these energy consumptions are available (except the MV line supplying the ITC transformer). The overall (simplified) scheme of electrical net of research area is shown in Fig. 3.

\section{HEATING AND COOLING PLANTS}

The heating and cooling plants are based on:

- a heating system, based on three gas boilers; two of the same size, used in winter, the third is used in the other seasons to provide after-heating for air conditioning units (hot tap water is produced locally by small electric boilers);

- a cooling system based on two water chillers cooled by cooling towers; the biggest one $(1350 \mathrm{~kW})$ was installed in the beginning, while the second one (740 $\mathrm{kW}$ ) was installed after the realization of last Institutes IGI-RFX.

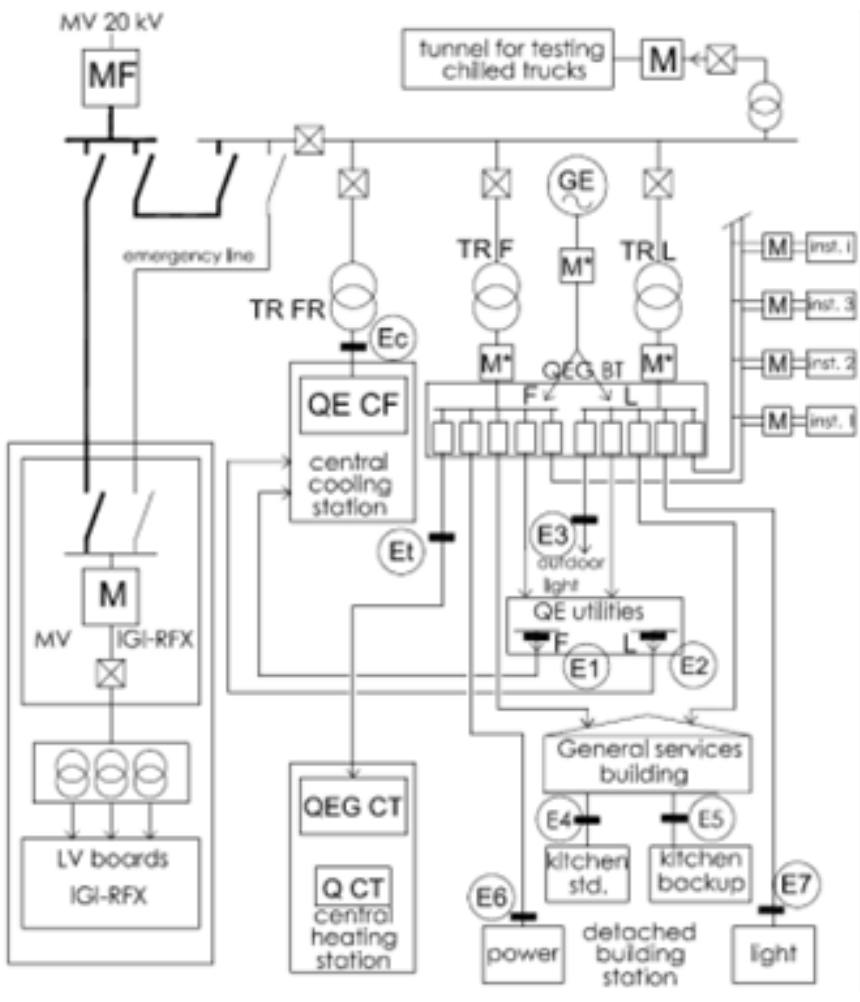

Fig. 3 - M,MF: existing energy meters; Et,Ec and Ej: new electrical energy measurement points. 
The distribution network for cooling pipes starts from the the manifold located in cooling central station; one branch supplies the general service building, the second supplies the IGI-RFX, the third supplies other Institutes (see Figs. 4, 12). Distribution network is the same for heating pipes (see Figs. 4, 11)
For heating and cooling, no energy meters had been installed (until 2012) to measure energy consumption of heating and cooling systems. Primary energy sources are electricity for cooling system; gas and electricity for cooling system (see Figs. 11, 12).

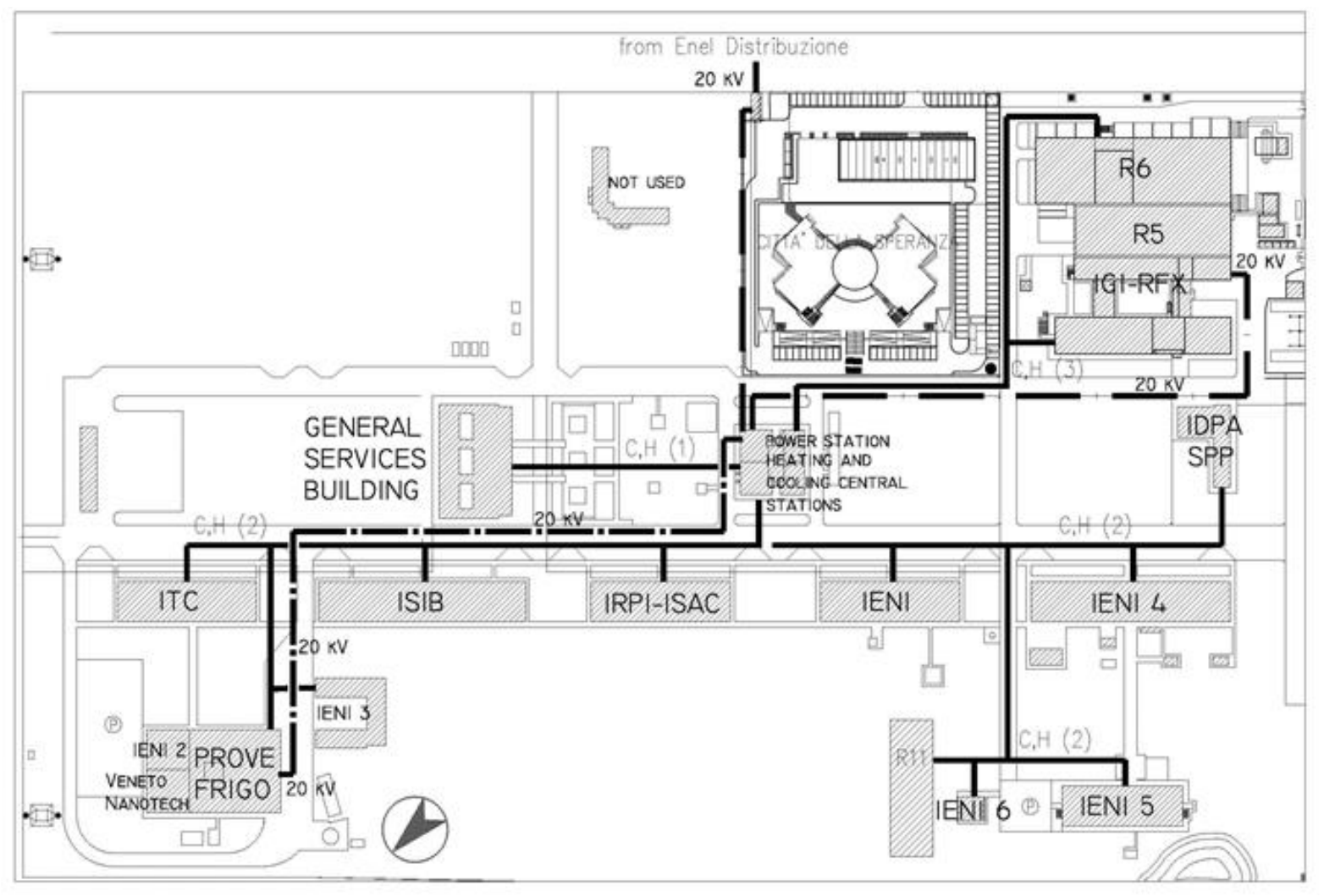

Fig. 4 - Scheme of MV distribution (- - - -) net and district heating (H) and cooling (C) (four pipes; water for sanitary uses and fire extinguishing system has the same path) - see also Figs. 11 and 12.

\section{GAS AND WATER DISTRIBUTION}

The gas (methane) is distributed to all buildings: the largest consumption is attributed to central heating station and the canteen. The gas is also distributed to Institutes, used for laboratory scopes. A unique energy meter is installed at the Area boundary (see Fig. 5).

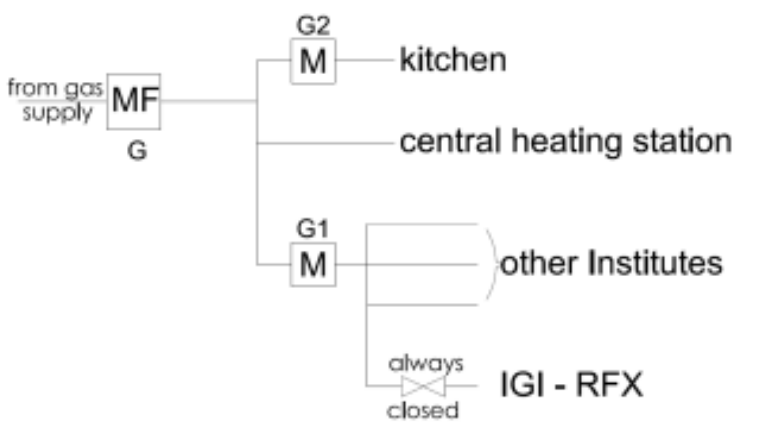

Fig. 5. Simplified scheme of gas distribution.
Water is distributed to all the buildings for sanitary use. A dedicated distribution system, supplied by a central pumping station, provides water for firefighting devices. For water distribution, a unique energy meter is installed at the Area inlet (Fig. 6).

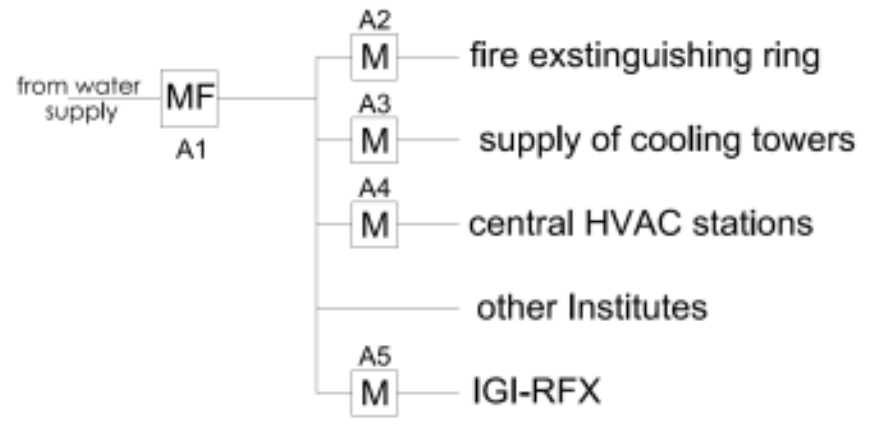

Fig. 6. Simplified scheme of water distribution. 


\section{FORMER BILLING SYSTEM}

Criterion for energy costs sharing until 2013 were based upon an agreement between various Institutes; sharing was based on building size and the number of people working in each Institute was also considered. Only the electricity consumption of each institute could be measured; the other energy costs were charged to each institute on the above mentioned criteria.

The energy costs of general services building were distributed among the Institutes by using the same criterion, taking into account the part of general services used by each institute.

\section{ENERGY SAVING AND COST OPTIMIZATION}

A dedicated team was created in 2013 to optimize overall billing system (Fig. 7). After a detailed analysis, the following issues have been found. There are mainly three user categories:

- general service building (offices, cafeteria and canteen, shared meeting rooms and library),

- IGI- RFX (offices plus a large experiment room with precise indoor climate requirements),

- other Institutes.

IGI-RFX has a wide use of treated air for spaces heating and conditioning, while other Institutes and general service building are conditioned with fan-coils and primary air supplied by indoor air handling units; furthermore, the IGIRFX hosts a fusion experiment that requires precise control of indoor temperature and relative humidity. The buildings named R5 (room hosting experiment and maintenance area (see Fig. 2) and R6 (experiment power supplies) are equipped with outdoor air handling units to ensure proper indoor conditions [5].

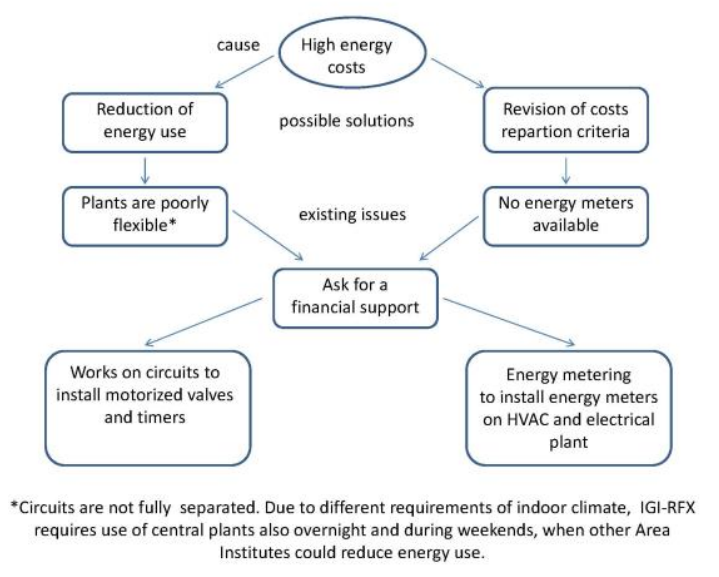

Fig. 7. The rational scheme followed for optimization.

There are some limitations:

- current configuration of plants does not allow separation of circuits supplying different buildings;

- IGI-RFX always need hot and chilled water to supply air conditioning units dedicated to R5 and R6;
- during winter, water has to be circulated in the outdoor heating network (hosted in underground tunnels) to prevent icing;

- hot water is requested by IGI-RFX also in warm seasons to ensure humidity control of the conditioned air (in fact, electrical and diagnostics systems are sensible to UR -more than temperature - that shall be maintained in the range of 40-60\%), while other Institutes, equipped with primary air and fan coils systems, have no so stringent requirements.

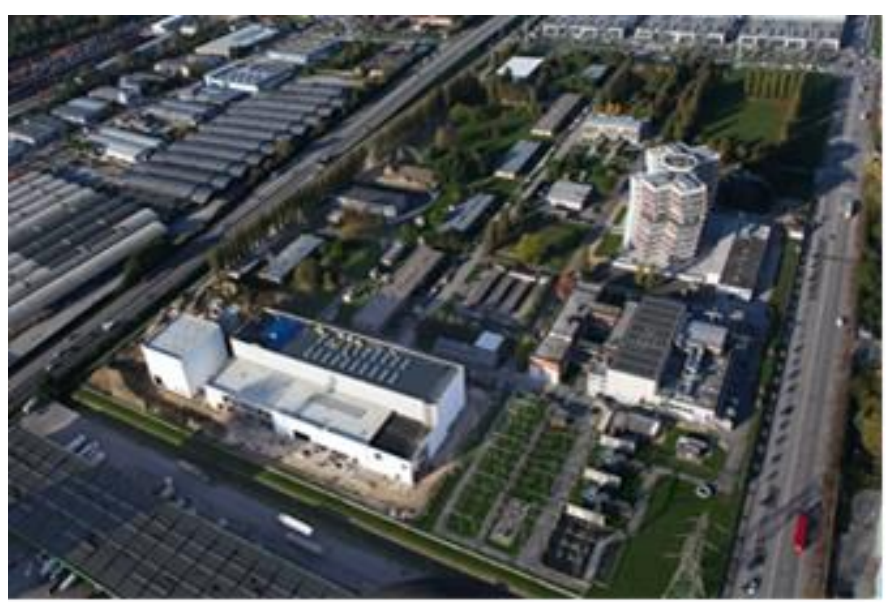

Fig. 8. Padova CNR research Area in 2013 [6].

Previous plant configuration (until 2013) did not allow reduction of centralized hot and cold water production due to requirements of IGI-RFX; this fact caused extra-costs for other institutes.

\section{IMPROVEMENT OF HEATING PLANTS}

Requirements for heating plants consist in the possibility to distribute hot water only to IGI-RFX during winter weekends, nights and holidays. Water circulation shall be ensured at least in the underground piping to prevent icing (tunnels are accessible somewhere for maintenance scopes, so tunnel internal temperature can reach the outdoor temperature).

The modifications on heating station are (see also Fig. 9):

- installation of two anti-freeze circulators $C_{1}, C_{2}$ to ensure proper hot water circulation in outdoor pipes (all the building except IGI-RFX);

- installation of two three-ways valves $\mathrm{V}_{1}, \mathrm{~V}_{2}$ and realization of by-passes;

- installation of programmable timer to control circulators and valves operations.

As a consequence, the operation of the centralized plants has been changed as follows:

- during winter work hours, circulators $\mathrm{C}_{1}, \mathrm{C}_{2}$ are shut down, by-passes are closed $\left(\mathrm{V}_{1}, \mathrm{~V}_{2}\right)$, all the buildings are supplied by main pumps;

- during winter holidays/nights hours, circulators $\mathrm{C}_{1}, \mathrm{C}_{2}$ are operated to ensure water circulation in the part of network supplying general building service $\left(\mathrm{C}_{1}\right.$, Fig. 4) and other Institutes $\left(\mathrm{C}_{2}\right)$; by-passes are open $\left(\mathrm{V}_{1}, \mathrm{~V}_{2}\right)$, only IGI-RFX is supplied by hot water produced by gas heaters;

- when heating is no longer necessary for warm outdoor 


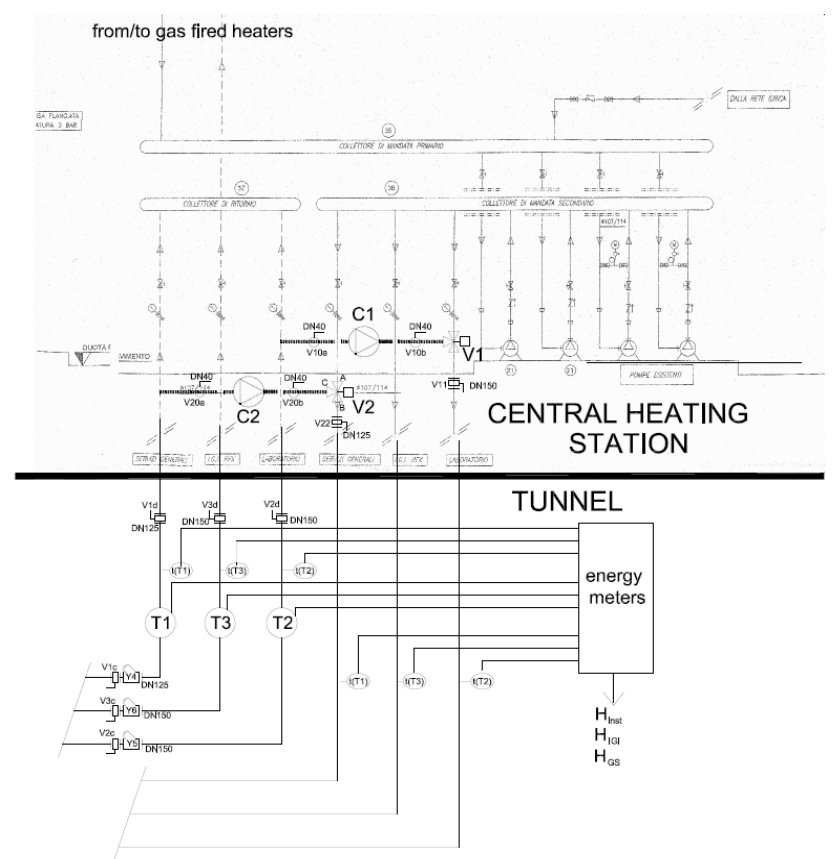

Fig. 9. Modification in central heating station: new manual and electrical operated valves $\left(\mathrm{V}_{1}, \mathrm{~V}_{2}\right)$ and circulators $\left(\mathrm{C}_{1}, \mathrm{C}_{2}\right)$ are shown. New energy meters on each branch $\left(\mathrm{T}_{1}, \mathrm{~T}_{2}, \mathrm{~T}_{3}\right)$ and thermal sensors $\left(\mathrm{t}\left(\mathrm{T}_{1}\right)\right.$, etc.) are also shown (measurements $\mathrm{H}_{\text {inst }}, \mathrm{H}_{\mathrm{IGI}}$ and $\mathrm{H}_{\mathrm{GS}}$ are provided).

temperatures, hot water is produced for IGI-RFX only if required by air handling units for humidity control (after heating); other circuits are intercepted $(\mathrm{V} 1, \mathrm{~V} 2)$ and circulators $\mathrm{C} 1, \mathrm{C} 2$ are not operated.

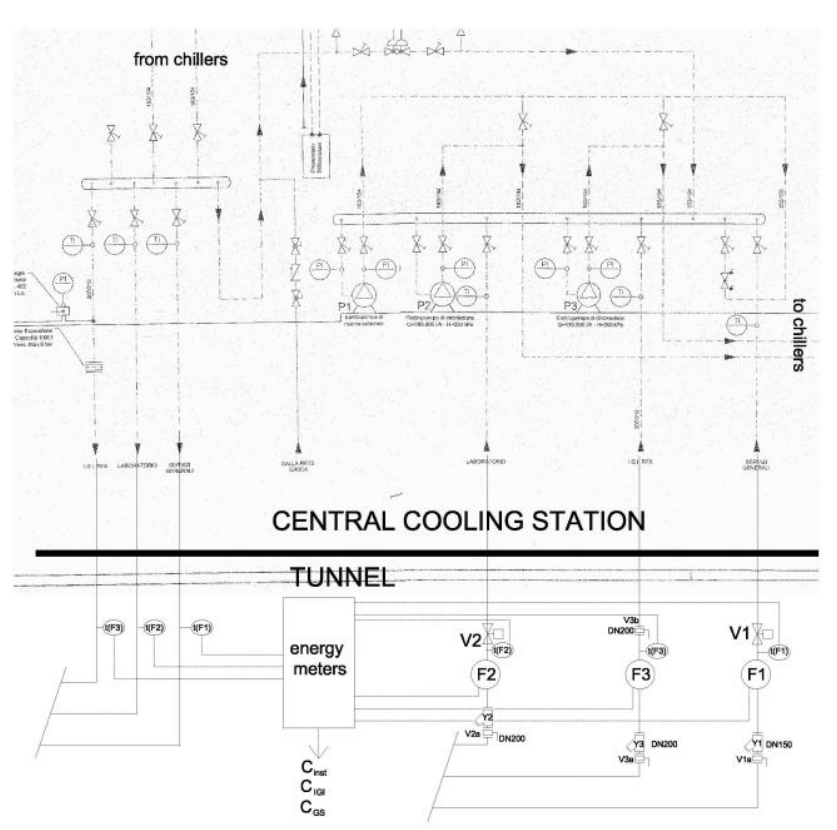

Fig. 10. Modification in central cooling: new manual and electrical operated valves $\left(\mathrm{V}_{1}, \mathrm{~V}_{2}\right)$ are shown. New energy meters on each branch $\left(\mathrm{F}_{1}, \mathrm{~F}_{2}, \mathrm{~F}_{3}\right)$ and thermal sensors $\left(t\left(F_{1}\right)\right.$, etc.) are also shown (measurements $\mathrm{C}_{\mathrm{inst}}, \mathrm{C}_{\mathrm{IGI}}$ and $\mathrm{C}_{\mathrm{GS}}$ are provided).

\section{VIII.IMPROVEMENT OF COOLING PLANTS}

New requirement for the cooling plants is to distribute chilled water only to IGI-RFX during weekends, nights and holidays, avoiding water circulation in the remaining circuits.

The modifications on cooling station are (see also Fig. 10):

- installation of two motorized valves $\mathrm{V}_{1}, \mathrm{~V}_{2}$;

- installation of programmable timer to control valves operations.

As a consequence, the operation of the centralized plants has been changed as follows:

- during summer work hours, valves $\left(\mathrm{V}_{1}, \mathrm{~V}_{2}\right)$ are open and all the buildings are supplied by main pumps;

- during other hours, only IGI-RFX is supplied by chilled water (valves $\mathrm{V}_{1}, \mathrm{~V}_{2}$ are closed).

\section{IMPROVEMENT OF BILLING SYSTEM}

With regard to the works required by the modifications in the centralized heating and cooling plants (pipe cutting, replacement of thermal insulation, etc.), low additional cost due to meters of thermal $\left(\mathrm{T}_{1}, \mathrm{~T}_{2}, \mathrm{~T}_{3}\right)$ and cooling energy $\left(\mathrm{F}_{1}, \mathrm{~F}_{2}, \mathrm{~F}_{3}\right)$ metering and related thermocouples $\left(t\left(T_{1}\right), t\left(T_{2}\right), \ldots\right.$ etc. $)$ has been added. This is a trade-off: energy meters were installed not everywhere but only close to heating and cooling central stations during a one week plants shutdown, in spring 2013. This allows controlling thermal and cooling energy used by general service building (HGS, CGS) and IGI-RFX ( $\left.\mathrm{H}_{\mathrm{IGI}}, \mathrm{C}_{\mathrm{IGI}}\right)$ : for other institutes, the overall values (Hinst, Cinst) need to be distributed among various Institutes (except IGI-RFX) using former criterion but improved the fact they have the same construction typology, making cost sharing based on buildings size and personnel number more realistic. It must be pointed out that installation of energy meters for each institute is much more expensive, it requires long out-of-order time and only a marginal advantage in billing system can be obtained: final solution consists of six energy meters for thermal and cooling energy.

Concerning the electrical bills, a selection of main important loads was done (Table I) to improve the billing system with acceptable installation costs. 
TABLE I

LIST OF ENERGY METERS FOR ELECTRICITY [4]

\begin{tabular}{|c|c|c|}
\hline $\begin{array}{l}\text { Energy } \\
\text { meters } \\
\text { code }\end{array}$ & Board name & Supplied board \\
\hline Ec & $\begin{array}{l}\text { Power station - LV } \\
\text { general board } \\
\text { (cooling section) }\end{array}$ & Central cooling station \\
\hline Et & \multirow{4}{*}{$\begin{array}{l}\text { Power station - LV } \\
\text { general board }\end{array}$} & Central heating station \\
\hline $\mathrm{E} 1$ & & $\begin{array}{c}\text { General service building } \\
\text { board - power }\end{array}$ \\
\hline $\mathrm{E} 2$ & & $\begin{array}{c}\text { General service building } \\
\text { board - light }\end{array}$ \\
\hline E3 & & Outdoor light \\
\hline $\mathrm{E} 4$ & \multirow{2}{*}{$\begin{array}{l}\text { General service } \\
\text { building: ground floor }\end{array}$} & $\begin{array}{l}\text { Kitchen }- \text { standard } \\
\text { power }\end{array}$ \\
\hline E5 & & $\begin{array}{c}\text { Kitchen - power backup } \\
\text { by a generator set (GE } \\
\text { in Fig. } 3 \text { ) }\end{array}$ \\
\hline E6 & \multirow{2}{*}{$\begin{array}{l}\text { General service } \\
\text { building: detached } \\
\text { station }\end{array}$} & $\begin{array}{l}\text { Power for general } \\
\text { service building }\end{array}$ \\
\hline E7 & & $\begin{array}{l}\text { light for general } \\
\text { service building }\end{array}$ \\
\hline
\end{tabular}

\section{ENERGY CALCULATIONS}

For the generic Institute (except IGI-RFX), thermal energy can be expressed as:

$$
\begin{aligned}
E_{h, i}= & \left(G+E_{t}\right) \cdot F_{h, i}^{*} \frac{H_{i n s t}}{H_{\text {inst }}+H_{G S}+H_{I G I}}+ \\
& +\left(G+E_{t}\right) \cdot F_{G S, i} \frac{H_{G S}}{H_{\text {inst }}+H_{G S}+H_{I G I}}
\end{aligned}
$$

where the first addendum represents the thermal consumption of the "i" Institute and the second addendum represents the contribution of this institute to the thermal energy used by the general service building; $G$ is the total amount of the gas methane (expressed in $\mathrm{kWh}$ ), $\mathrm{E}_{\mathrm{t}}$ is the electrical energy used by central heating station (figure 03 ), $\mathrm{H}_{\mathrm{inst}}, \mathrm{H}_{\mathrm{IGI}}$ and $\mathrm{H}_{\mathrm{GS}}$ are the values measured by thermal energy meters (see figure 11), $\mathrm{F}_{\mathrm{h}, \mathrm{i}}{ }^{*}$ is the coefficient of use of thermal energy related to institute " $i$ " (except IGI-RFX), $F_{\mathrm{GS}, \mathrm{i}}$ is the coefficient of use of general services related to institute "i" $i$ ". Factor $\mathrm{F}_{\mathrm{h}, \mathrm{i}}{ }^{*}$ is function of buildings dimensions, $S / V$ ratio etc., the factor $F_{G S, i}$ is a function of number of personnel units of institute "i".

For the IGI-RFX, the cooling energy can be expressed as:

$$
\begin{gathered}
E_{c, I G I}=\left(E_{c}\right) \cdot \frac{C_{I G I}}{C_{i n s t}+C_{G S}+C_{I G I}}+ \\
+\left(E_{c}\right) \cdot F_{G S, I G I} \frac{C_{G S}}{C_{i n s t}+C_{G S}+C_{I G I}}
\end{gathered}
$$

(1); $E_{C}$ is the electrical energy used in by cooling plant, $C_{i n s t}$, $\mathrm{C}_{\mathrm{IGI}}$ and $\mathrm{C}_{\mathrm{GS}}$ are the values measured by cooling energy

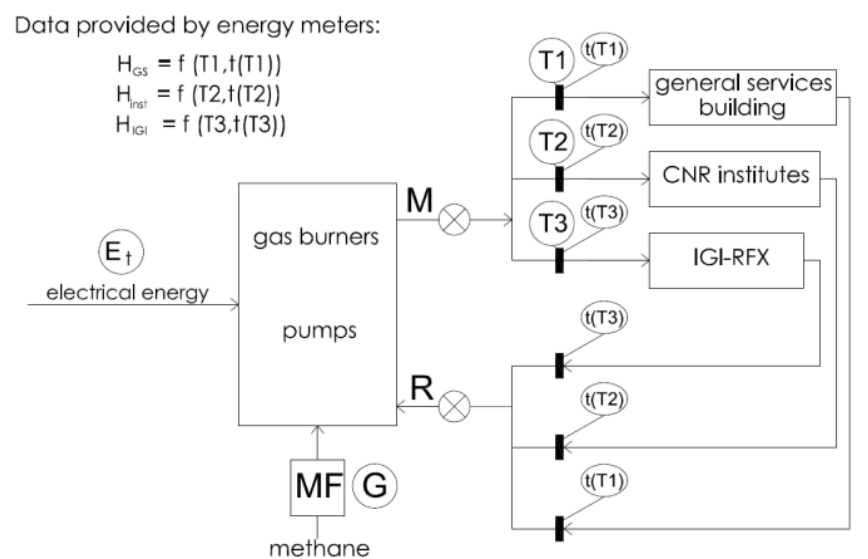

Fig. 11. Thermal energy distribution scheme (M supply, $\mathrm{R}$ return, $\mathrm{t}$ thermal sensors).

meters (Fig. 12).

Finally, the electrical energy used by a generic institute "i" is:

$E_{e, i}=\left(E_{i}\right)+F_{G S, i} \cdot\left(\sum_{j=1}^{7} E_{j}\right)$

where the first addendum represents the electrical consumption of the "i" Institute and the second represents the contribution of this institute to the electrical energy used by the general service building, as measured by new energy meters $E_{j}$ (see Table I).

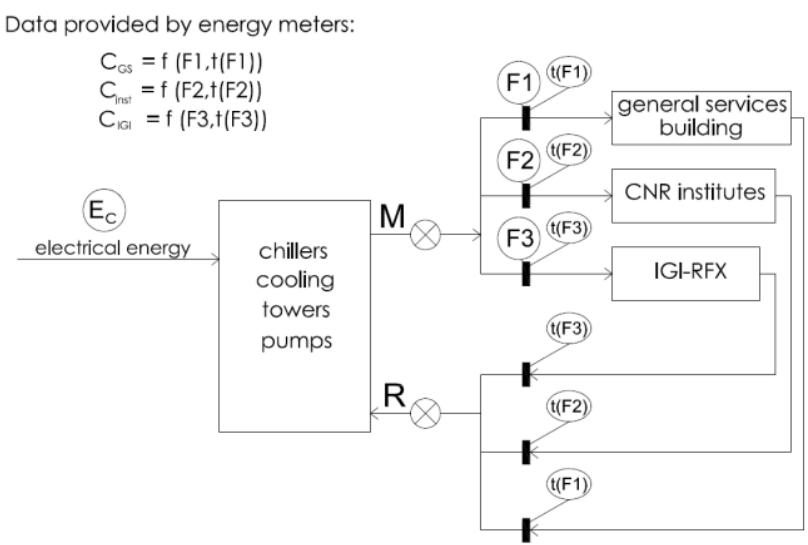

Fig. 12. Cooling energy distribution scheme ( $M$ supply, $R$ return, $t$ thermal sensors)

\section{DATA FROM ENERGY METERS}

In Table II the first data from new energy meters related to cooling energy consumptions are shown. 
TABLE II

COOLING AND ELECTRICAL ENERGY: ABSOLUTE VALUES

\begin{tabular}{|c|c|c|c|c|c|c|}
\hline \multicolumn{3}{|c|}{2014} & $\mathrm{C}_{\text {inst }}$ & $\mathrm{C}_{\mathrm{GS}}$ & $\mathrm{C}_{\mathrm{IGI}}$ & $\mathrm{E}_{\mathrm{c}}$ \\
\hline from & to & days & \multicolumn{3}{|c|}{$\mathrm{MWh}_{\mathrm{c}}$} & $\mathrm{MWh}_{\mathrm{e}}$ \\
\hline $1 / 7$ & $28 / 7$ & 27 & 140 & 12.2 & 192.6 & 15.4 \\
\hline $28 / 7$ & $3 / 11$ & 63 & 74.1 & 21 & 459.1 & 37.4 \\
\hline $3 / 11$ & $1 / 12$ & 27 & 0 & 0 & 86.3 & 4.1 \\
\hline
\end{tabular}

These data need to be interpreted; for this purpose Tables III and IV contain the data on other parameters, like time (Table III), time and gross buildings volume (Table IV).

TABLE III

COOLING ENERGY CONSUMPTION: DAILY AVERAGE

\begin{tabular}{|c|c|c|c|c|}
\hline \multicolumn{2}{|c|}{2014} & $\mathrm{C}_{\text {inst }}$ & $\mathrm{C}_{\mathrm{GS}}$ & $\mathrm{C}_{\mathrm{IGI}}$ \\
\hline from & to & $\mathrm{MWh} / \mathrm{d}$ & $\mathrm{MWh} / \mathrm{d}$ & $\mathrm{MWh} / \mathrm{d}$ \\
\hline $1 / 7$ & $28 / 7$ & 5.19 & 0.45 & 7.13 \\
\hline $28 / 7$ & $3 / 11$ & 1.11 & 0.31 & 6.85 \\
\hline $3 / 11$ & $1 / 12$ & 0.00 & 0.00 & 3.08 \\
\hline
\end{tabular}

The general service building is most compact (less value of $\mathrm{S} / \mathrm{V}$ ratio) and has less glass surfaces than other buildings; this is the reason for less cooling consumption during summer, when other buildings typology (IGI-RFX and other CNR Institutes) has similar summer consumption (first row in Table III). In the second and third rows of Table III, different amount of cooling energy used by IGI-RFX is explained.

TABLE IV

SPECIFIC COOLING ENERGY CONSUMPTION: DAILY AVERAGE PER VOLUME

\begin{tabular}{|c|c|c|c|c|}
\cline { 3 - 5 } \multicolumn{2}{c|}{} & $\mathrm{C}_{\text {inst }}$ & $\mathrm{C}_{\mathrm{GS}}$ & C $_{\text {IGI }}$ \\
\hline volume & $\mathrm{m}^{3}$ & 27500 & 9000 & 42000 \\
\hline from & to & $\mathrm{kWh} / \mathrm{m}^{3}$ & $\mathrm{kWh} / \mathrm{m}^{3}$ & $\mathrm{kWh} / \mathrm{m}^{3}$ \\
\hline $1 / 7$ & $28 / 7$ & 0.19 & 0.05 & 0.17 \\
\hline $28 / 7$ & $3 / 11$ & 0.04 & 0.03 & 0.16 \\
\hline $3 / 11$ & $1 / 12$ & 0.00 & 0.00 & 0.07 \\
\hline
\end{tabular}

Due to big volumes of air conditioned in the buildings, the IGI-RFX has - also in autumn - similar consumption as in summer (first row, Table IV); only during November (third row) the energy consumptions decreases.

In Table $\mathrm{V}$ the first data from new energy meters related to cooling energy are shown.

Energy consumptions for cooling plants (column D) are similar to consumptions for other uses, like auxiliaries of central stations (except cooling central station) and outdoor light, (column A). The canteen (column B) has a constant consumption with an average of $95 \mathrm{kWh}$ for each work day (canteen is open from Monday to Friday). Consumptions of November (last row) only $152 \mathrm{kWh} / \mathrm{d}$. The main energy cooling plants (column D) depend strongly on weather conditions; in July the average is around $463 \mathrm{kWh} / \mathrm{d}$., such consumption is due to the general services building (except canteen), with an average of around $1500 \mathrm{kWh} / \mathrm{d}$.

TABLE V

ELECTRICAL ENERGY FOR COMMON SERVICES: A: OUTDOOR LIGHT, OTHER SERVICES; B: CANTEEN C: ILLLUMINATION AND POWER DISTRIBUTION OF GENERAL SERVICES BUILDING; D COOLING PLANTS

\begin{tabular}{|c|c|c|c|c|c|}
\cline { 3 - 5 } \multicolumn{2}{c}{} & \multicolumn{2}{c|}{$\begin{array}{c}\text { General services } \\
\text { building }\end{array}$} & cooling \\
\hline \multicolumn{2}{|c|}{2014} & $\mathrm{~A}$ & $\mathrm{~B}$ & $\mathrm{C}$ & $\mathrm{D}$ \\
\hline from & to & $\begin{array}{c}\mathrm{E}_{1}+\mathrm{E}_{2} \\
+\mathrm{E}_{3} \\
{[\mathrm{MWh}]}\end{array}$ & $\begin{array}{c}\mathrm{E}_{4}+\mathrm{E}_{5} \\
{[\mathrm{MWh}]}\end{array}$ & $\begin{array}{c}\mathrm{E}_{6}+\mathrm{E}_{7} \\
{[\mathrm{MWh}]}\end{array}$ & $\begin{array}{c}\mathrm{E}_{\mathrm{c}} \\
{[\mathrm{MWh}]}\end{array}$ \\
\hline $9 / 6$ & $1 / 7$ & 9.6 & 2.0 & 22.3 & 12.5 \\
\hline $1 / 7$ & $28 / 7$ & 11.2 & 2.0 & 26.2 & 15.5 \\
\hline $28 / 7$ & $3 / 11$ & 37.6 & 8.5 & 97.6 & 37.4 \\
\hline $3 / 11$ & $1 / 12$ & 7.5 & 1.9 & 25.1 & 4.1 \\
\hline
\end{tabular}

\section{CONCLUSIONS}

Energy savings due to plant modifications are estimated to be around $10 \%$ considering the same operative and weather conditions. These investment costs will be confirmed by the undergoing analysis of data acquired.

But the main advantage associated with meter installation is the possibility, for each user, to know the actual amount of energy consumed. This knowledge should push people to adopt better practice in energy saving, and this goal is obtained with limited investment costs.

\section{ACKNOWLEDGMENT}

The author is grateful to Simone Zucchetti for the collaboration during works on plant modifications and for supplying the data.

\section{REFERENCES}

[1] Consiglio Nazionale delle ricerche, Area della Ricerca di Padova [Online].Available:

http://www.pd.cnr.it/index.php/it/informazioni/informazioni-generali [Accessed: Dec. 1, 2014].

[2] RFX: the esperiment [Online]. Available: http://www.igi.cnr.it/?q=content/experiment-introduction [Accessed: Dec. 1, 2014].

[3] Photo from website. [Online]. Available: http://cartografia.comune.padova.it/mappe/index.html?extent=1729104, 5029967,1729725,5030377 [ Accessed: Nov.201, 2014].

[4] L. Fellin, "ripartizione dei costi dei consumi energetici tra area e "Consorzio RFX", 2013.

[5] F. Fellin, internal reports on CNR Area energy consumptions, 2013

[6] Aerial view, photo of Alberto Salvagno (www.studioph.it) 